\title{
Recombinant Human Erythropoetin in Children with Chronic Renal Failure (A Preliminary Report)
}

Husein Alatas

\begin{abstract}
Abstrak
Eritropoetin rekombinan telah diberikan pada enam anak dengan gagal ginjal kronik (klirens kreatinin $<30 \mathrm{ml} / \mathrm{menit} / 1,73 \mathrm{~m}{ }^{2}$ dan 2 diantaranya dengan gagal ginjal terminal dalam terapi Dialisis Peritoneal Mandiri Berkesinambungan (CAPD). Eritropoetin rekombinan ( $r$-Hu-Epo = Rekombinant Human Eritropoetin) diberikan secara subkutan dengan dosis awal $150 \mu / \mathrm{kg} / \mathrm{bb} / \mathrm{kali}$ per minggu dan dinaikkan setiap minggu $75 \mu / \mathrm{kg} / \mathrm{bb}$ sampai kadar hemoglobin $>10 \mathrm{~g} / \mathrm{dl}$ dan kemudian dosis dipertahankan pada level tersebut. menjadi $8.45+1.77 \mathrm{~g} /$ dl dan 8 ming semua penderita. Kadar $\mathrm{Hb}$ sebelum pemberian $\mathrm{r}$-Hu-Epo $6.93 \pm 1.76 \mathrm{~g} / \mathrm{dl}, 4 \mathrm{minggu}$ pascaterapi pascaterapi naik menjadi $26.42+7.07 \%$, dan 8 mingadi $8.78 \pm 2.69 \mathrm{~g} / \mathrm{dl}$. Kadar Hematokrit sebelum terapi $23.10 \pm 4.95 \%, 4$ minggu ( Pada 2 orang anak yang sebelumnya bahaya infeksi hepatitis, hemosiderosis dan sensitisasian $r$-Hu-Epo tidak memerlukan transfusi lagi dengan demikian terhindar dari menurun dengan demikian menunjukkan sensitisasi terhadap HLA antigen histokompatibilitas. Kadar serum feritin pascaterapi peningkatan tekanan darah pada dua anak tapi dengaran Fe untuk membentuk eritrosit. Efek samping yang ditemukan adalah minggu sebelumnya, tekanan darah menurun. Pada laporan penambahan dosis antihipertensi dan pengurangan dosis $r$-Hu-Epo seperti gagal ginjal kronik stadium lanjut, yaitun. Pada laporan pendahuluan ini didapat kesan $r$-Hu-Epo memberi efek baik pada penderita lain harganya yang masih
\end{abstract}

\section{Abstract}

Recombinant human erythropoetin ( $r$-Hu-Epo) was administered to six children with chronic renal failure (creatinine clearance $<30 \mathrm{~mL} / \mathrm{m} / 1.73 \mathrm{~m}^{2}$ ). Two of these children suffered from terminal renal failure and received contimuous ambulatory peritoneal dialysis (CAPD). An initial dose of $150 \mu / \mathrm{kgBW} /$ week $r$-Hu-Epo was administered subcutaneously. The dose was increased by $75 \mu / \mathrm{kgBW} /$ week $\pm 1.77 \mathrm{~g} /$ dl after 4 weeks and $8.78 \pm 2.69 \mathrm{~g} / \mathrm{ll}$ afer $10 \mathrm{~g} / \mathrm{dl}$. The hemoglobin level rose from $6.93 \pm 1.76 \mathrm{~g} / \mathrm{dl}$ before treatment to 8.45 of therapy. The reticulocyte count increased while the serum freatment to $26.42 \pm 7.07 \%$ after 4 weeks and $29.85 \pm 9.95 \%$ after 8 weeks utilized for promoting the production of erythrocye in the borritin level decreased during treatment. Thus indicated that Fe was being no further transfusions were needed, thus preventint in the bone marrow. In 2 cases previously requiring multiple blood transfusions, antigen. An increase in blood pressure was the side effect detected in and reducing the r-Hu-Epo dose to the level of the prevffect detected in 2 cases. This was corrected by adding an antihipertensive drug drug in restricting multiple blood transuion use is still limited.

Keywords : R-Hu-Epo, Chronic renal failure, Anemia, Hypertension

\section{INTRODUCTION}

Anemia is one of the major complications in renal failure, which leads to the necessity of repeated blood transfusions and the consequent risks and complications. Regular blood transfusion may correct the anemia temporarily, but as mentioned before, it is associated with certain risks such as iron overload, transmission of viral infections, and increased production of lymphocytotoxic antibodies. ${ }^{1,3}$

Recently, recombinant human erythropoetin ( $\mathrm{r}-$ $\mathrm{Hu}$-Epo) has been made available. Animal experiments have shown it to be effective in correcting anemia in chronic renal failure. Recent trials on adults and children receiving hemodialysis or peritoneal dialysis as maintenance therapy have shown prompt 
resolution of anemia after administration of $\mathbf{r}-\mathrm{Hu}$ Epo. ${ }^{6,7}$ Hypertension has been the most frequently reported side effect in r-Hu-Epo therapy, but in the majority of the patients, blood pressure was easily controlled by adding hypotensive drugs. ${ }^{8,9}$

The purpose of this study is to evaluate the efficacy and safety of r-Hu-Epo in 6 children with anemia due to chronic renal failure. Changes in hemoglobin and hematocrit levels, reticulocyte count as well as serum ferritin level were correlated to the r-Hu-Epo administration. Potential side effects were noted, especially changes in blood pressure which have frequently been reported in the literature. ${ }^{8}$

\section{MATERIALS AND METHODS}

Six patients, consisting of 4 males and 2 females with a mean age of 12.5 years, were entered in this study after parental informed consent were obtained (table 1). The patients were all diagnosed as chronic renal failure with a creatinine clearance of $<30 \mathrm{ml} / \mathrm{min} / 1.73$ $\mathrm{m}^{2}$. Two of these children suffered from terminal renal failure (creatinine clearance $<5 \mathrm{ml} / \mathrm{min} / 1.73 \mathrm{~m}^{2}$ ) and was on continuous ambulatory peritoneal dialysis (CAPD) treatment. The etiology was nephrotic syndrome in 4 patients and chronic pyelonephritis in 2 patients. The inclusion criteria for r-Hu-Epo administration were:

1. age between $1-16$ years

2. no other causes of anemia, such as thallasemia, sickle cell anemia, etc.

3. no persistent severe hypertension

4. no abnormal liver function

The drug was injected subcutaneously with a starting dose of $150 \mu / \mathrm{kgBW}$ weekly for 4 successive weeks while waiting for a response. An increase of $1 \mathrm{~g} / \mathrm{dl} / \mathrm{month}$ was a suitable guideline for adequate response. The dose was then titrated by adding 75 $\mu / \mathrm{kgBW} /$ week and maintained for a further 4 successive weeks. When the target hemoglobin of $10 \mathrm{~g} / \mathrm{dl}$ was reached, the titration phase was concluded and the $\mathrm{r}-\mathrm{Hu}-\mathrm{Epo}$ dose was maintained at this level.

Laboratory tests to evaluate renal and liver functions, serum ferritin, hemoglobin $(\mathrm{Hb})$ and hematocrit levels $(\mathrm{Ht})$, and reticulocyte count were recorded as baseline data. After r-Hu-Epo therapy was initiated, the $\mathrm{Hb}, \mathrm{Ht}$, and reticulocyte count were repeated every two weeks, while serum ferritin levels were re-examined after 4 weeks and at the end of drug level titration. Blood chemistry was evaluated monthly to monitor renal and liver functions. Iron supplementation was given during treatment, to maintain the ferritin level within a normal range. Any patient can receive blood transfusion when necessary.

Potential side effects were noted during treatment. Blood pressure was carefully measured prior to and 30 minutes after r-Hu-Epo injection. It was monitored daily in the hospitalized patients or biweekly in ambulatory patients on follow up examinations.

The quality of life was recorded monthly by means of a questionaire to observe any improvement or deterioration of the well being of the patients. Special emphasis was made on the changes in appetite, physical fitness and school attendance.

Statistical significance ( $p$ value) for the paired data was not calculated, since the number of patients in this preliminary report was small. Values are expressed as mean \pm SD.

Table 1. Clinical data of patients at the time of entry

\begin{tabular}{lcll}
\hline No & Age (years) & Sex & Etiology of CRF \\
\hline 1 & 10 & M & N.S. \\
2 & 13 & F & CPN \\
3 & 12 & M & N.S.(CAPD) \\
4 & 12 & F & N.S. \\
5 & 14 & M & CPN \\
6 & 14 & M & N.S.(CAPD) \\
\hline
\end{tabular}

NS : Nephrotic Syndrome

CPN : Chronic Pyelonephritis

\section{RESULTS}

The preliminary results of this study showed that in the first 4 and 8 weeks of $r$-Hu-Epo administration, the $\mathrm{Hb}$, $\mathrm{Ht}$, and reticulocyte count were increased in all patients (fig. 1,2,3). Hemoglobin levels rose from $6.93 \pm 1.76$ $\mathrm{g} / \mathrm{dl}$ to $8.45 \pm 1.77 \mathrm{~g} / \mathrm{dl}$ after 4 weeks and $8.78 \pm 2.69$ after 8 weeks of treatment. Hematocrit levels rose from $23.10 \pm 4.95 \%$ to $26.42 \pm 7.07 \%$ after 4 weeks and $29.85 \pm 9.95 \%$ after 8 weeks of treatment. Reticulocyte count rose from $1.02 \pm 0.44 \%$ to $2.87 \pm 1.64 \%$ after 8 weeks of therapy (table 2). In 2 patients who required multiple blood transfusion prior to treatment, no further transfusions were needed after $\mathbf{r}$-Hu-Epo administration.

Increased blood pressure was observed in 2 patients. However, the blood pressure could be controlled by adding the antihypertensive drug captopril and reducing the r-Hu-Epo dose to the level of the preceeding week (figure 4).

Results from the questionaire showed that appetite was improved. The patients became more active after the administration of r-Hu-Epo. 
Table 2. The effects of treatment with $\mathrm{r}-\mathrm{Hu}$-Epo on hemoglobin, hematocrit and reticulocyte count

\begin{tabular}{lccr}
\hline & Before & \multicolumn{2}{c}{ After Epo } \\
\cline { 3 - 4 } & EPO & 4 weeks & 8 weeks \\
\hline $\mathrm{Hb}(\mathrm{g} / \mathrm{dl})$ & $6.93 \pm 1.76$ & $8.45 \pm 1.77$ & $8.78 \pm 2.69$ \\
$\mathrm{Ht}(\%)$ & $23.10 \pm 4.95$ & $26.42 \pm 7.07$ & $29.85 \pm 9.95$ \\
Reti (\%) & $1.02 \pm 0.44$ & - & $2.87 \pm 1.64$ \\
\hline
\end{tabular}

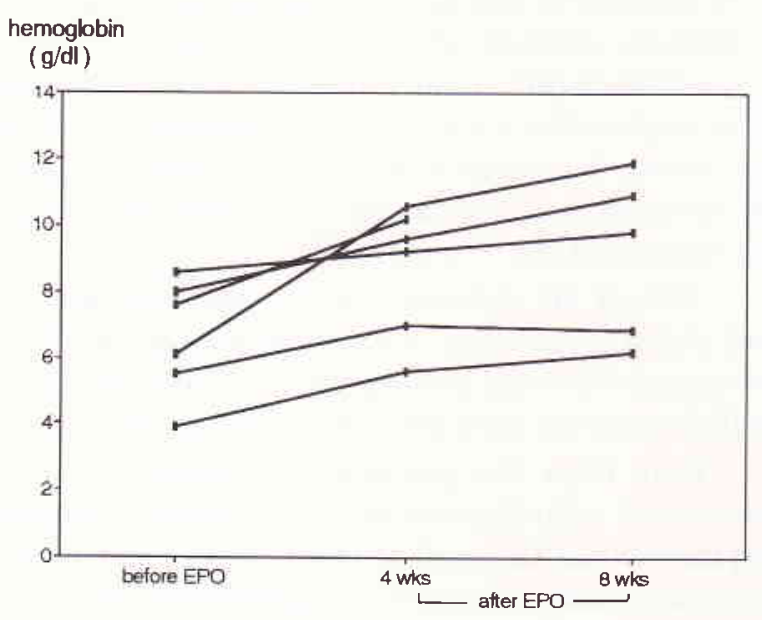

Figure 1. Hemoglobin concentration before and during treatment with $r-H_{u}-E$ po

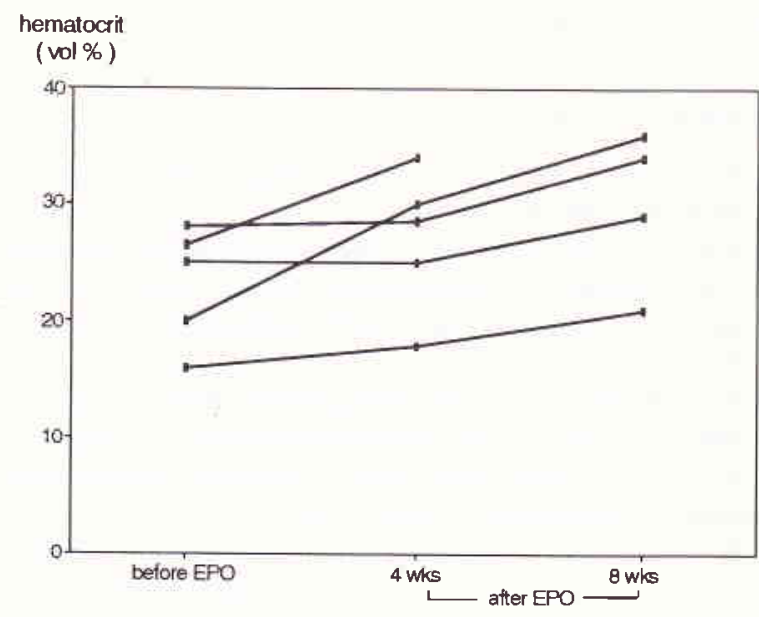

Figure 2. Hematocrit values before and during treatment with r-Hu-Epo

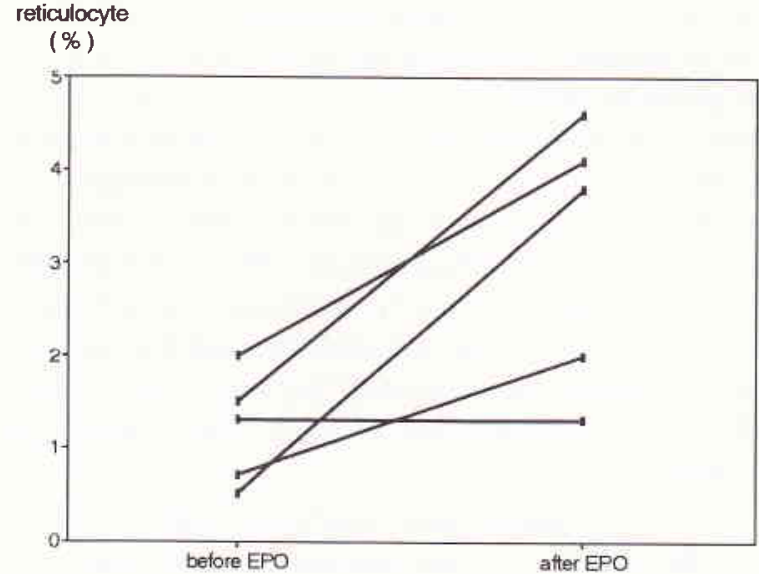

Figure 3. Reticulocyte count before and during treatment with r-Hu-Epo

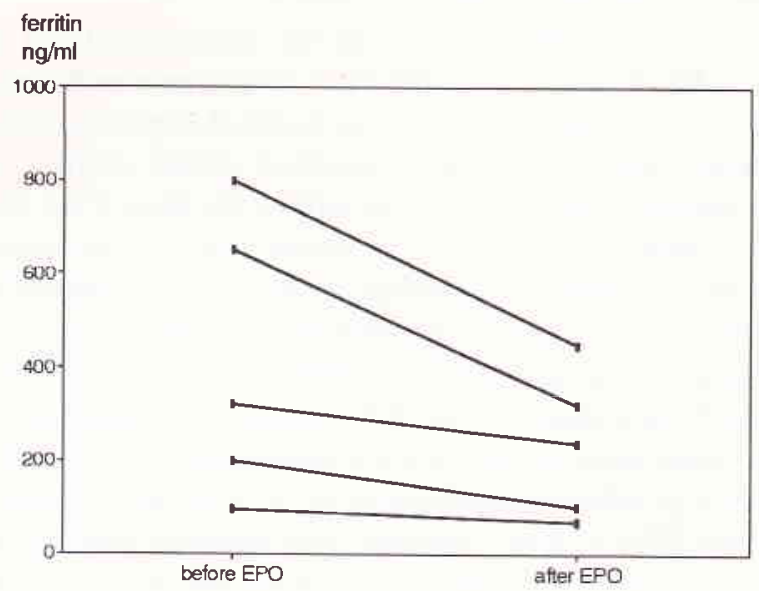

Figure 4. Ferritin level before and during treatment with $r-H u$ Epo

\section{DISCUSSION}

The synthesis of recombinant human erythropoetin ( $\mathrm{r}-\mathrm{Hu}-\mathrm{Epo})$ is a significant advantage in the treatment of anemia due to chronic renal failure. Earlier studies reported promising results in the treatment of renal anemia in hemodialyzed patients. ${ }^{4,5,10}$ More recent reports described the use of this drug in children as well as adults patients on continous ambulatory peritoneal dialysis (CAPD) and predialysis patients. ${ }^{6,7}$ 
Either intravenous or subcutaneous administration, which is clearly more practical in predialysis and CAPD patients, produced no significant difference in the pharmacokinetic or efficacy evaluation. ${ }^{11}$ In this study, $\mathrm{r}-\mathrm{Hu}$-Epo was administered to 4 predialysed and 2 CAPD patients. The results showed an increase in $\mathrm{Hb}$ and Ht levels, as well as reticulocyte count. This demonstrated that subcutaneous $\mathrm{r}-\mathrm{Hu}$-Epo was effective. In 2 cases previously requiring multiple blood transfusions, no further transfusion needed to be given, thus preventing the dangers of hepatitis, AIDS, hemosiderosis, or sensitization of HLA histocompatibility antigens.

Several studies have confirmed the efficacy of $\mathrm{r}$-Hu-Epo in improving anemia in end stage renal failure patients not yet requiring dialysis therapy. Lim et al treated 14 anemic patients with intravenous r-HuEpo in a double blind placebo-controlled trial and reported an increase in mean hemoglobin levels from $9.1 \pm 0.2$ (se) to $12.3 \pm 0.4 \mathrm{~g} / \mathrm{dl}$ over a 2 month period. ${ }^{6}$ Escbach et al had administered r-Hu-Epo in 17 predialysis patients with anemia and observed a median rise of hematocrit from 0.27 to $0.37 .^{7}$

It is important to measure the serum iron level in patients treated with r-Hu-Epo. In patients with iron deficiency, indicated by a low level of serum ferritin, ferrum should be supplemented either orally or parenterally, in conjunction with $\mathrm{r}-\mathrm{Hu}-\mathrm{Epo}$. This ensures iron is adequate for the production of erytrocytes in the bone marrow. Findings in this study showed that serum ferritin level decreased and reticulocyte count increased during $\mathrm{r}$-Hu-Epo treatment, which indicated that ferrum was utilized for erytrocyte production in the bone marrow. As was recommended, ferrous sulfate was administered orally in 3 cases with normal serum ferritin level. Patients with repleted iron levels can develop iron deficiency under the influence of r-Hu-Epo. ${ }^{12,13}$

Partial correction of anemia in chronic renal failure with r-Hu-Epo is the best treatment, since a linear increase in the hemoglobin and hematocrit levels leads to an exponential rise in whole body viscosity. ${ }^{14}$ This is thought to contribute to many side effects in r-Hu-Epo therapy, such as hypertension, increased peripheral resistance and thrombotic complication. Based on this consideration a rise of $1 \mathrm{~g} / \mathrm{dl} / 4$ weeks appears to be the best compromise and the optimum target of hemoglobin level seems to be in a range of $10-12 \mathrm{~g} / \mathrm{dl}^{15}$

The target $\mathrm{Hb}$ level in this study was set at $10 \mathrm{~g} / \mathrm{dl}$ as the end point of the r-Hu-Epo titration dose. This minimizes possible complications of treatment. Nevertheless, 2 cases of moderate hypertension was ob- served. However, a combination of captopril and reducing r-Hu-Epo dose by $75 \mu / \mathrm{kgBW} /$ week or returning to the dosage of the previous week was sufficient to control the blood pressure. No other side effects was observed in this study.

Hypertension was indeed the most frequently reported side effect associated with $\mathrm{r}-\mathrm{Hu}$-Epo therapy. 8,9 Results of multicenter clinical trials involving 309 patients showed that $72 \%$ patients with existing hypertension were in no greater risk of acquiring increased blood pressure than those who were normotensive at the beginning of treatment. Only $39 \%$ of the patients were reported as having developed sustained increase in diastolic pressure of $10 \mathrm{mmHg}$ or more. ${ }^{16}$ The increased blood pressure in r-Hu-Epo therapy is thought to be mediated by a number of pathophysiologic changes namely increased blood viscosity, increased peripheral resistance, and failure in reducing the elevated cardiac output due to anemia. ${ }^{16}$

Almost all children showed improved appetite and physical activities. This along with a significant increase in $\mathrm{Hb}$ were also reported by Suhardjono et al in their study on adult patients receiving $\mathrm{r}-\mathrm{Hu}-\mathrm{Epo}{ }^{8}$

Data from this preliminary clinical trial have shown that $\mathbf{r}-\mathrm{Hu}$-Epo has promising effect in increasing the $\mathrm{Hb}$ and $\mathrm{Ht}$ levels in children with anemia due to chronic renal failure. This minimizes multiple blood transfusions and the adverse effects caused. The high cost, however, limits the widespread use of this drug.

\section{Acknowledgement}

The author is grateful to Janssen Research Council Indonesia for their support in providing the $\mathrm{r}-\mathrm{Hu}$ Epo drugs in this clinical trial.

\section{REFERENCES}

1. Savazzi GM. Pathogenesis of cerebral atrophy in uremia. Nephron 1988; 49 : 94-103.

2. Scharer K, Muller-Wiefel D. Hematological complications. Complications in Renal Failure in Holiday, Barratt, Vernier. eds. Pediatric Nephrology. 2nd Ed. Baltimore: Williams \& Wilkins, 1987; 880-7.

3. Winearls CG, Oliver DO, Pippard MJ, Reid C, Downing MR, Cotes PM. Effects of human erythropoetin derived from recombinant DNA on the anaemia of patients maintained by chronic hemodialysis. Lancet 1986; 2 : 1175 - 8.

4. Eschbach JW. The anaemia of chronic renal failure : pathophysiology and the effects of recombinant human erythropoetin. Kidney Int 1989; 35 : 134 - 48.

5. Montini G, Zocchello G, Baraldi E, et al. Benefits and risks of anemia correction with recombinant human erythropoetin in children maintained by hemodialysis. J Pediat 1990; 117 : 566 . 
6. Lim VS, De Gowin RL, Zarada D, et al. Recombinant human erythropoetin treatment in predialysis patients a doubleblind placebo-controlled trial. Ann Intern Med 1989; 110 : 108 14.

7. Eschbach JW, Kelly MR, Haley NR, Abels RI, Adamson JW. Treatment of the anemia of progressive renal failure with recombinant human erythropoetin. N Eng J Med 1989; $321: 158-163$.

8. Suhardjono, Rahardjo P, Markum MS, Sumardjono, Sukadis I, Sidabutar RP. Pengobatan anemia pada gagal ginjal kronik dengan Eritropoetin Rekombinan. Maj Kedok Indones 1991; $41: 591-4$.

9. Roger SD, Baker LRI, Raine AEG. Autonomic dysfunction and the development of hypertension in patients treated with recombinant human erythropoetin ( $\mathrm{r}-\mathrm{Hu}-\mathrm{Epo}$ ). Clin Nephrol $1993 ; 39: 103-10$.

10. Casati S, Passerini P, Campise MR, et al. Benefit and risks of protracted treatment with human recombinant erythropoetin in patients having haemodialysis. $\mathrm{Br} \mathrm{Med} \mathbf{J} 1987 ; 295$ : $1017-20$.
11. Stevens JM, Strong CA, Oliver DO, Winearls CG, Cotes PM. Subcutaneous erythropoetin and peritoneal dialysis. Lancet 1989; i : 1388 - 9.

12. Sinai-Trieman L, Salusky IB, Fine RW. Use of subcutaneous recombinant human erythropoetin in children undergoing continuous cycling peritoneal dialysis. J Pediatr 1989; 114 : $550-4$.

13. Mac Dougall IC, Hutton RD, Carill I, Coles GA, Williams JD. Poor response to treatment of renal anaemia with erythropoetin corrected by iron given intravenously. $\mathrm{Br} \mathrm{Med}$ J 1989; $299: 157$ - 8.

14. Frenken LAM, Wezels JFM, Shiter HE, Koene RAP. Evidence for renal vasodilation in predialysis patients during correction of anemia by erythropoetin. Kidney Int 1992; 41 : 384 - 7 .

15. Mac Dougall IC, Hutton RD, Coles GA, Williams JD. The use of erythropoetin in renal failure. Postgrad Med J 1991; $67: 9-15$

16. Levin N. Management of blood pressure changes during recombinant human erythropoetin therapy. Semin Nephrol 1989; 9 (suppl 2) : $16-20$. 